\title{
Mechanisms of hypolimnion erosion in a deep lake (Lago Maggiore, N. Italy)
}

\author{
Walter AMBROSETTI*, Luigi BARBANTI and Elisabetta A. CARRARA ${ }^{1)}$ \\ C.N.R. Institute for Ecosystem Study, L. Tonolli 50, 28922 Verbania-Pallanza, Italy \\ ${ }^{1)}$ Current address: Water Division, Bureau of Meteorology, Melbourne, Vic. 3008, Australia \\ *e-mail corresponding author: w.ambrosetti@ise.cnr.it
}

\begin{abstract}
Holo-oligomixis is one of the most important hydrodynamic characteristics of deep lakes in temperate regions, especially those of the Southern Alps. It influences such important lake chemical and biological processes as the oxygenation of deep layers, recycling of nutrients, vertical migration of plankton, and reproduction. Analysis of physico-chemical data from Lago Maggiore over the years 1951 - 2008 has shown that in addition to ever active but relatively inefficient convective mixing, three other mechanisms act to oxygenate this lake's deep waters in winter. These are conveyor belt currents, cold and well-oxygenated tributary inflows that sink down to depths of equal density, and differential cooling of littoral waters that subsequently slide down the lake flanks. Their common outcome is to cause deep erosion of the hypolimnion. Heat content and thermal stability also are affected and are analyzed here in relation to external driving forces, examining in particular how dynamics may be altered by climate change.
\end{abstract}

Key words: holo-oligomixis, deep oxygenation dynamics, deep erosion, heat content, thermal stability

\section{INTRODUCTION}

Recent research in physical limnology carried out on deep lakes, by I.S.E. - C.N.R. in Pallanza, Italy, is directed towards identification of the main characteristics of thermal and hydrodynamic seasonal cycles. Such signs of a slow but progressive alteration of physical processes as increased stability of a water body and reduced vertical mixing depth in winter were discovered in several deep Italian lakes (Ambrosetti et al. 2007). Similar alterations have been identified in lakes throughout the northern temperate zone, to the extent that they have become expected outcomes of the current global warming (Livingston 2003; Glenn 2005; Coats et al. 2006; Lemming \& Amouroux 2006). In essence, an increase in atmospheric temperature and in reflected infrared radiation has been found, in addition to modifications in precipitation and in the spatial distribution and intensity of wind (Ambrosetti et al. 2006). These altered conditions have affected entire lake ecosystems with the particular effects of increasing water residence time, reducing the speed of nutrient recycling, and decreasing oxygenation of deep water layers.

Apart from determining the distribution of particulate matter and dissolved substances in water, vertical turbulence, transport and mixing also define the environment in which bio-geochemical reactions can occur (Salmaso 2005; Rueda 2006). Therefore it is essential to have detailed understanding of how hydrodynamics has changed when producing a sound plan for the conservation and recovery of a disturbed lake. As has been the case in other fields of applied research, use of mathematical models may play a decisive role in generating simulations that improve understanding of the spatial and temporal dynamics of water velocity, temperature, density, mass, and chemical species distributions in lakes. We are strongly convinced of the efficacy of this research direction and thus are involved in the creation of a 3D model of Lago Maggiore based on the general model Computational Fluid Dynamics (see Castellano et al. 2008). However, we are also certain of the necessity for greater understanding of the mechanisms that regulate the physical structure of deep lakes to avoid the possibility that the application of these models is reduced to a purely numerical exercise. Consequently the aim of this work is to use data on the system dynamics of Lago Maggiore from 1951 to 2008 to analyze the various transport mechanisms that at the end of the limnological winter determine the oxygenation of hypolimnetic layers.

\section{METHODS}

The depths reached by vertical winter mixing from 1951 to 2008 have been evaluated in two ways: 1) vertical profiling of physical and chemical parameters at Lago Maggiore's deepest point $(370 \mathrm{~m})$ using inverted thermometers and multi-parameter probes: and 2) indirect use of the so called ' $\mathrm{M}$ ' (Mixing) parameter, which takes into consideration the influence of the meteorological variables responsible for homogenization of the lake water body. The first approach was applied over the period 1963 - 2008 and the second from 1951-2008.

Temperature and dissolved $\mathrm{O}_{2}$ concentrations were measured initially on a monthly basis, but more frequently beginning in 1977 , especially during the presumed winter circulation. The depth of the mixing layer was taken to be the deepest level at which weak temperature gradients were observed and therefore where it 


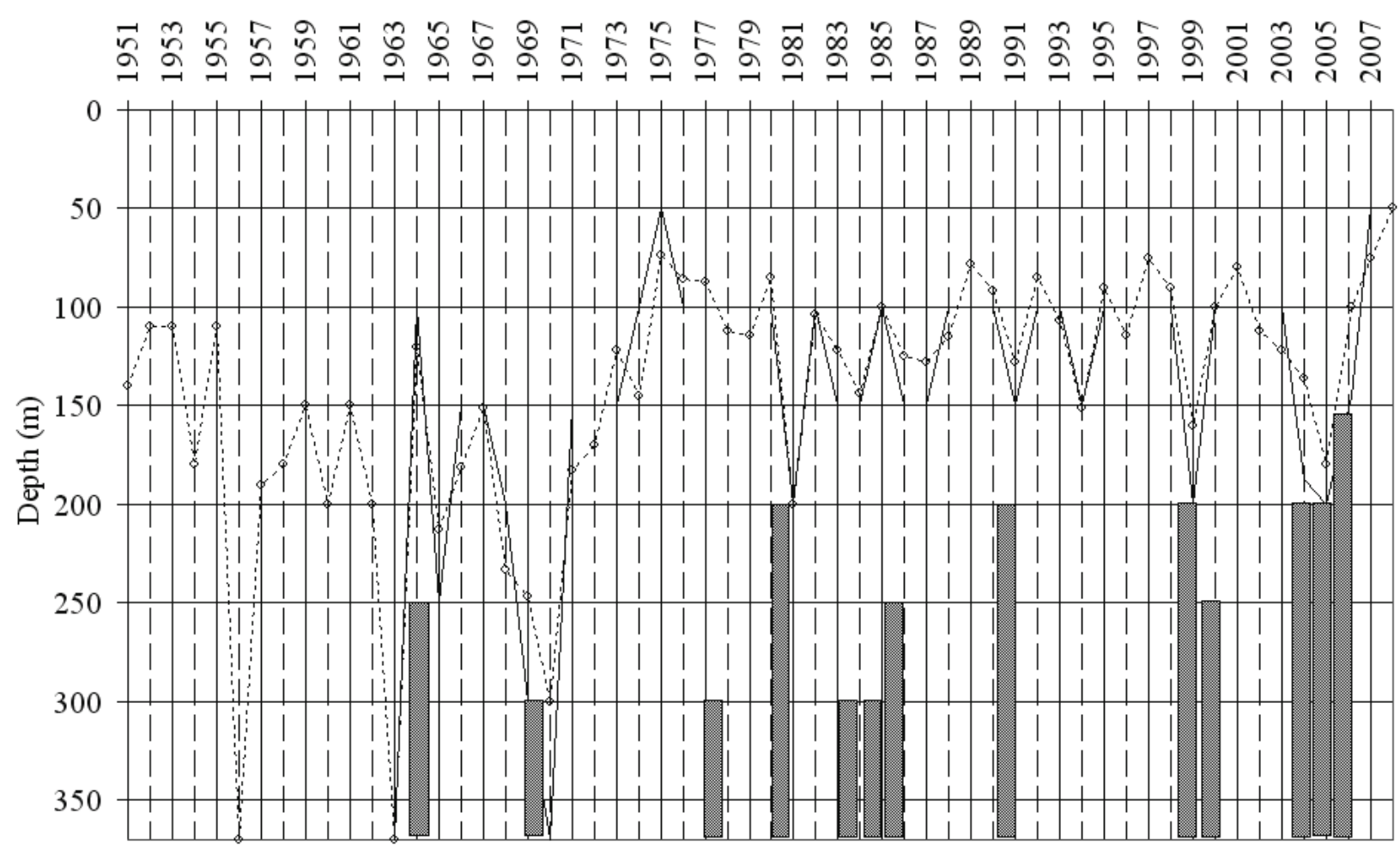

Fig. 1. Mixing depth measured in situ (solid line) and calculated via the parameter M (dotted line). The histogram indicates the thickness of the oxygenated hypolimnetic layer.

was still possible to identify the presence of convective motion. Chemical data such as dissolved $\mathrm{O}_{2}$ concentration were also analysed to support the thermal data. Below the mixing level a noticeable reduction in the concentrations of $\mathrm{O}_{2}$, silicate and nitrate generally occurred, except during certain hydrological events. Standard methodology was used to measure chemical concentrations.

Those limnological and meteorological variables involved in the destabilization of the summer thermal stratification, and which influence vertical heat distribution, are used in the calculation of M. The data used were recorded at the ISE-CNR Pallanza monitoring station located along the lake shore and near the geographical centre of Lago Maggiore. The variables measured include: wind force, which is responsible for turbulent movements; solar radiation energy, responsible for the floating mechanism, and which opposes turbulence; and the difference between water and air temperature $(\Delta \mathrm{T})$ at the lake's surface. This last value is very important for evaluation of the energy components of the lake's thermal balance, which also include the variables global solar radiation, reflected solar radiation, net long-wavelength energy exchange, sensible heat conduction and the heat utilised in evaporation (Ambrosetti et al. 2003).

Thermal stability (Walker 1974) and heat content were assessed by means of the LIMNOX program (Ferris 1989), which allows for the calculation of both the total heat integrated over the entire water column and of its distribution meter by meter.

\section{RESULTS AND DISCUSSION}

\subsection{Depth of winter mixing}

Figure 1 shows the depth reached by convective mixing as evaluated using in-situ measurements (continuous line) and calculation of $\mathrm{M}$ (dotted line). The two lines show almost perfect alignment even though below $100 \mathrm{~m}$ the in situ measurements were made at $50 \mathrm{~m}$ intervals. From 1971 on, parameter M consistently indicates partial mixing, with a maximum mixing depth of $200 \mathrm{~m}$ in 1981. This shows that in these years there was less kinetic energy than needed to initiate sufficient turbulence for complete winter turnover during the formation of the so called 'new water'. This caused a stagnation of the deep layers for several years (Ambrosetti \& Barbanti 1999).

As recognized by Vollenweider (1964) the total mixing events have meteorological causes that can be diverse in their features. For example, low solar radiation may combine with a high $\Delta \mathrm{T}$ (as in the 1956 episode), or strong consistent winds may accompany high $\Delta \mathrm{T}$ (as in the 1963 episode). In 1970 the complete mixing revealed by on site measures was caused by a combination of all three of the these factors. On this occasion, however, the depth indicated by parameter $\mathrm{M}$, which synthesises the meterological causes of convec- 


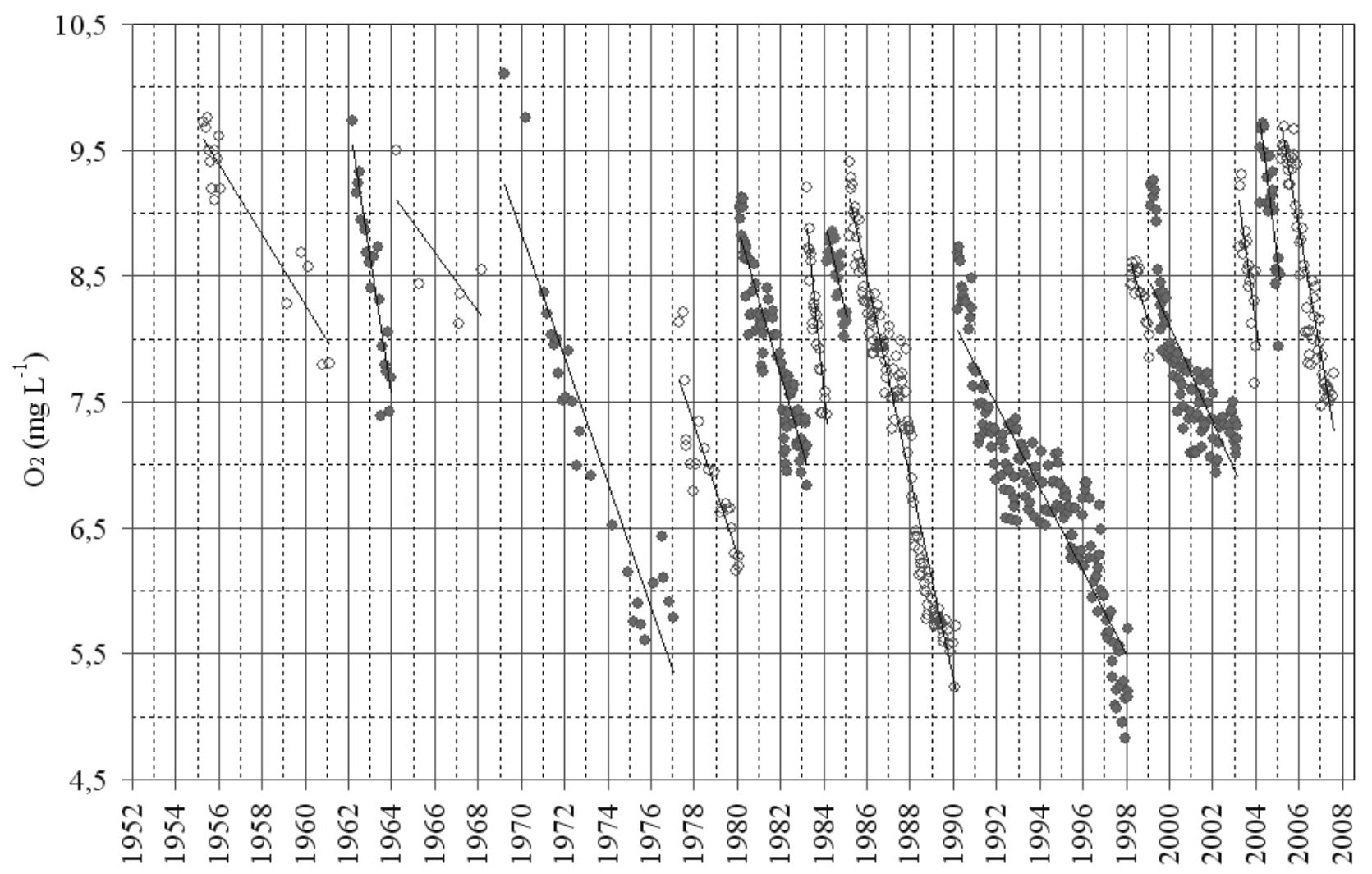

Fig. 2. Phases of reduction and increase in the dissolved $\mathrm{O}_{2}$ concentration in the deep water layer (250-370 m) from 1952 to 2008 . The regression lines are all significant $(p<0.001)$ with the exception of that for the 1965-1969 period.

tive mixing indicated by Vollenweider, was 'only' 300 $\mathrm{m}$. This led to the hypothesis that mechanisms beyond mixing convective processes were responsible for the event (Ambrosetti et al. 2003). The histogram presented in figure 1 shows the frequency of hypolimnetic oxygenation through mechanisms other than convection. These are discussed later in section 3.3.

\subsection{Oxygenation of the deep layers}

A robust cause and effect relationship links vertical circulation with the oxygenation of the deeper water layers and this relationship is such that even concentration of dissolved $\mathrm{O}_{2}$ is a valid parameter for evaluating the thickness of the mixed layer. Figure 2 shows the average dissolved $\mathrm{O}_{2}$ content of the lake below $250 \mathrm{~m}$ from 1952 to 2008. A series of cycles with a typical saw-tooth trend lasting several years and consisting of episodes of rapid and marked oxygenation followed by periods of dissolved $\mathrm{O}_{2}$ reduction is apparent. The dissolved $\mathrm{O}_{2}$ depletion phases were defined in mathematical terms using regression lines. The respective angular parameters that determine the average yearly rate of dissolved $\mathrm{O}_{2}$ consumption are represented in table 1 .

While the concentration of dissolved $\mathrm{O}_{2}$ in the late 1950 s to the 1960 s remained sufficiently high, in the following 30 years a series of prolonged depletions and rapid rises of dissolved $\mathrm{O}_{2}$ occurred. The lowest dissolved $\mathrm{O}_{2}$ concentration $\left(4.8 \mathrm{mg} \mathrm{L}^{-1}\right)$ was measured on 17 December 1998; after which the following $\mathrm{O}_{2}$ increase $\left(>7 \mathrm{mg} \mathrm{L}^{-1}\right)$ brought concentrations back to 1960s levels.

Tab. 1. Average annual oxygen consumption in periods of complete segregation of the deep layer. The periods refer to those in figure 2 .

\begin{tabular}{ccc}
\hline \multicolumn{2}{c}{ Period } & $\Delta \mathrm{O}_{2} \mathrm{mg} \mathrm{L}^{-1}$ \\
\hline 4-Apr-56 & 26-Feb-62 & 0.28 \\
4-Mar-63 & 14-Dic-64 & 1.11 \\
23-Mar-65 & 26-Feb-69 & 0.23 \\
18-Mar-70 & 30-Set-76 & 0.64 \\
13-Apr-78 & 5-Feb-81 & 0.51 \\
11-Feb-81 & 12-Mar-84 & 0.59 \\
22-Mar-84 & 7-Feb-85 & 1.77 \\
14-Feb-85 & 23-Gen-86 & 0.74 \\
4-Mar-86 & 14-Feb-91 & 0.79 \\
26-Feb-91 & 18-Feb-99 & 0.32 \\
10-Mar-99 & 27-Gen-00 & 0.57 \\
14-Feb-00 & 10-Feb-04 & 0.38 \\
15-Mar-04 & 31-Gen-05 & 1.33 \\
24-Feb-05 & 6-Feb-06 & 1.32 \\
22-Feb-06 & 28-Lug-08 & 0.99 \\
\hline
\end{tabular}

The 15 phases of $\mathrm{O}_{2}$ reduction indicated in figure 2 and in table 1 coincide only partly with those reported 


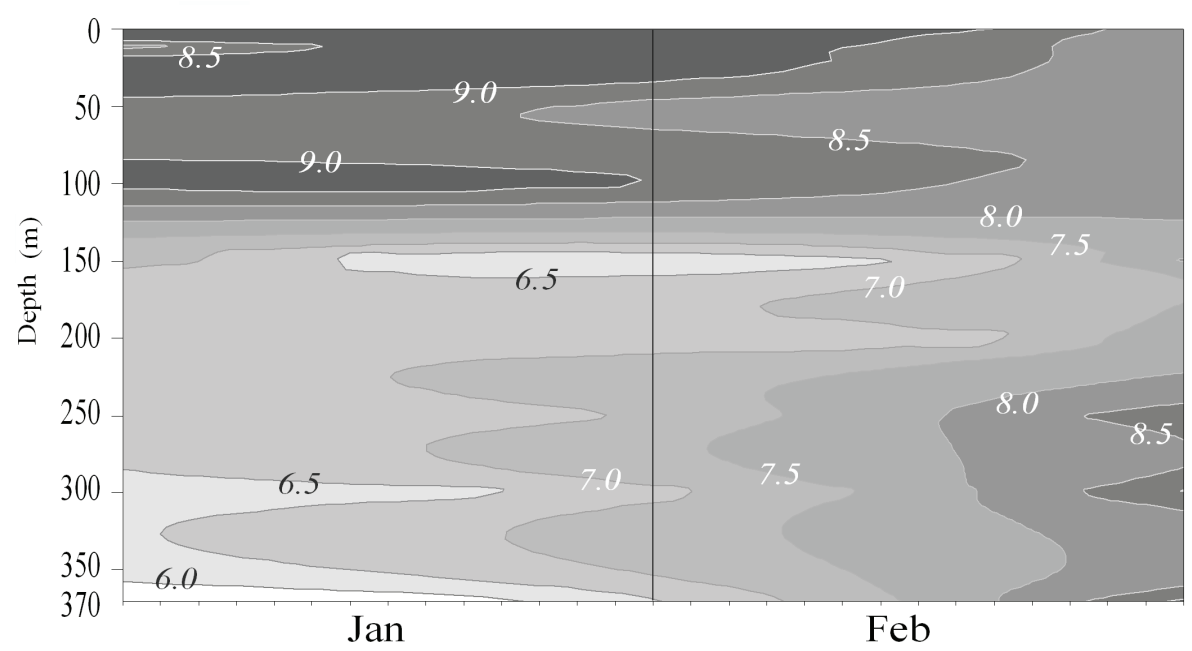

Fig. 3. Vertical distribution of $\mathrm{O}_{2}$ concentration $\left(\mathrm{mg} \mathrm{L}^{-1}\right)$ in winter 1981, showing the presence of a highly oxygenated layer below $200 \mathrm{~m}$ in mid February.

by Calderoni (1998) and then by Rogora et al. (2008) because we had more data available, and because the previous authors principally considered the trophic status of the lake rather than hydro-meteorological mechanisms. The fact remains, however, that apart from convective motion, other mechanisms exist that are capable of controlling $\mathrm{O}_{2}$ concentration in the deepest layers of the lake and therefore interrupting their prolonged isolation from the remaining water body. This is due to the morphometry of the lake and its catchment, and above all, to the hydro-meteorological conditions of the entire area. Lago Maggiore is a stretched out lake along its main north-south axis and is therefore directly affected by northerly winds.

\subsection{Oxygenation mechanisms}

A detailed analysis of the physical limnology of Lago Maggiore and other southern Alpine deep water bodies permits identification of three mechanisms besides convective mixing capable of transporting oxygen down to deep hypolimnetic waters. These are discussed in detail below.

\subsubsection{Conveyor belt circulation}

The effect on large Italian lakes of strong northerly winds at a particular angle to the water is to create drift currents rather than waves or vertical turbulence. The surface water is then moved towards the lee side of the lake where, impeded in its horizontal movement, it is forced to sink and flow on the lakebed in the opposite direction toward the windward side. Here it is drawn to the surface again to counterbalance the mass of water moved away. The result of all this, is a conveyor belt circulation that affects the top and bottom water of the lake and leaves a middle layer that is not affected by the currents. In winter 1981, a mixing mechanism of this kind occurred in Lago Maggiore (see Ambrosetti et al.
(1982) for details). The documentation of this phenomenon was possible thanks to a series of in situ vertical surveys of physical and chemical parameters carried out at short intervals along the $63 \mathrm{~km}$ long main longitudinal axis of Lago Maggiore.

The effects of the conveyor belt circulation on the vertical distribution of dissolved $\mathrm{O}_{2}$ are shown in figure 3. in February 1981, a layer of highly oxygenated water (up to $9 \mathrm{mg} \mathrm{L}^{-1}$ ) with physical, chemical and biological characteristics similar to shallower water $(0-120 \mathrm{~m})$, was found at depth below $200 \mathrm{~m}$. This deeper layer is clearly different from the middle layer $(120-200 \mathrm{~m})$ that has lower dissolved $\mathrm{O}_{2}$ content $\left(5.5-7 \mathrm{mg} \mathrm{L}^{-1}\right)$. These findings are supported by the dissolved $\mathrm{O}_{2}$ balance calculated for the intervals between surveys. The decrease in dissolved $\mathrm{O}_{2}$ content in the surface layer is closely balanced by the increase in dissolved $\mathrm{O}_{2}$ concentration in the deeper layer (Ambrosetti at al. 1982). The change in other chemical parameters such as electric conductivity, nitrates, reactive and total phosphorous and silicates between subsequent samplings also demonstrate the transport of the surface water towards greater depths. Finally biological studies of chlorophyll concentrations and suspended organic matter record similar concentrations at the surface and at depth, but very different concentrations in the central part of the water column (Callieri et al. 1982), and some species of copepods with minimal swimming ability have been found abundant in deeper layers although their food is near the surface. This demonstrates that they were transported to the bottom by currents of the conveyor belt mechanism (de Bernardi et al. 1983).

Ambrosetti et al. (1983) also indicated that the transport of oxygenated water at depth occurs quickly, thereby showing the presence of strong drift currents. The measured wind speeds during the 1981 mixing event were, on average, $4-6 \mathrm{~m} \mathrm{~s}^{-1}$. This wind intensity is not particularly high but as has been ascertained already 


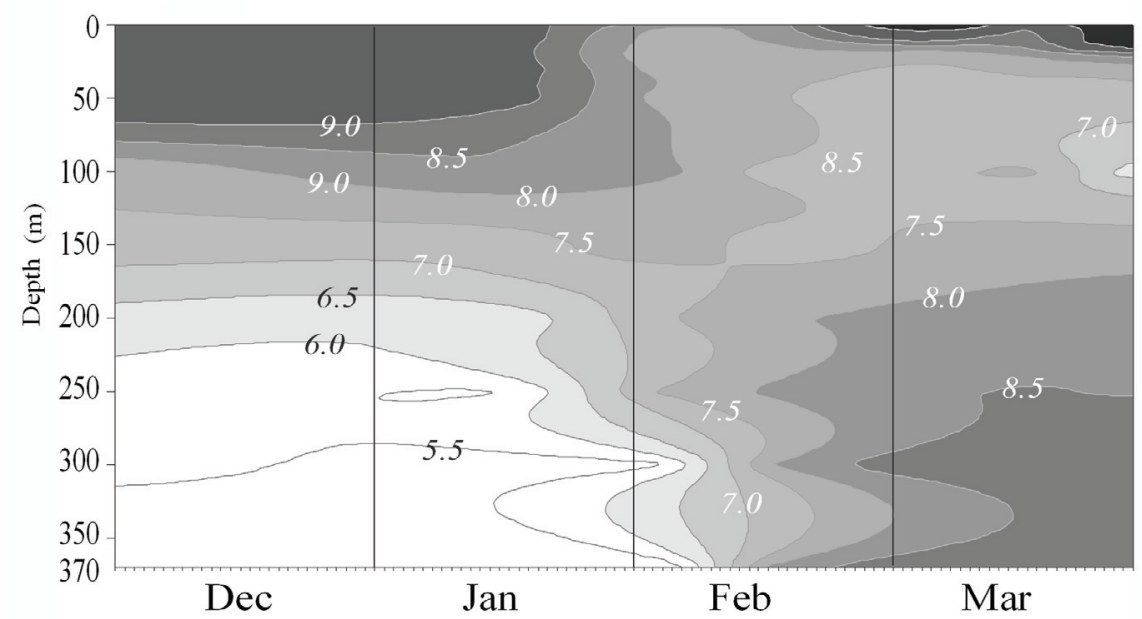

Fig. 4. Vertical distribution of dissolved $\mathrm{O}_{2}$ concentration $\left(\mathrm{mg} \mathrm{L}^{-1}\right)$ in winter 1991, showing the presence of a highly oxygenated layer below $200 \mathrm{~m}$ in mid February.

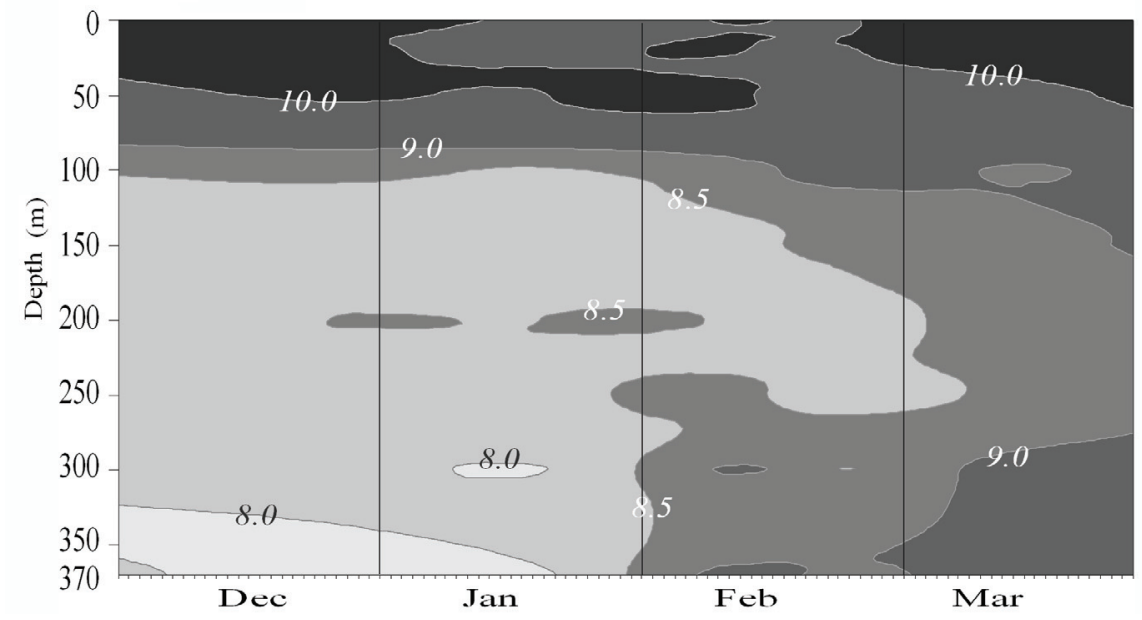

Fig. 5.Vertical distribution of dissolved $\mathrm{O}_{2}$ concentration $\left(\mathrm{mg} \mathrm{L}^{-1}\right)$ in winter 2000, showing the presence of a highly oxygenated layer below $250 \mathrm{~m}$ in mid February.

in other lakes of various dimensions and morphology (Haines \& Bryson 1961; Smith 1979; George 1981), it is of the order of magnitude required to trigger strong currents. In fact, stronger winds dissipate part of their energy in generating ripples, waves, and breakers at the cost of the drifting motion.

In the same winter (1981), a similar mixing event was recorded in the deep (189 m) Traunsee in Austria (Sossau \& Pechlaner 1988). Again in 2004, intrusion of cold oxygenated water at depth seems to have caused by conveyor belt circulation in not just Lago Maggiore but also other Italian water bodies.

\subsubsection{Sliding of fluvial water}

A second and diverse type of oxygenation mechanism of the deep hypolimnion that occurred on more than one occasion in Lago Maggiore, is the inflow of colder and denser fluvial water that consequently slide down to the lake bottom. Particularly effective have been waters from the Rivier Ticino, the River Maggia and the River Toce tributaries, all of which drain the more elevated parts of the basin. Records of the daily flow and water temperatures of these rivers are provided by UFAEG of the Swiss Confederation (personal communication) and are measured by CNR-ISE of Pallanza.

Episodes of deep inflow of fluvial water are documented for the winters of 1991 and 2000, and are shown respectively in figures 4 and 5 . In the first case from mid February, a highly oxygenated $\left(>9.0 \mathrm{mg} \mathrm{L}^{-1}\right)$ layer of water is shown forming below $200 \mathrm{~m}$. It is separated from surface water by a layer of water with low dissolved $\mathrm{O}_{2}$ concentration present at $\sim 150 \mathrm{~m}$, which subsequently is maintained from December until March. Almost the same situation is repeated in 2000 when a large mass of low dissolved $\mathrm{O}_{2}$ water, initially located between 100 and $300 \mathrm{~m}$ and then around $200 \mathrm{~m}$, separates two layers of highly oxygenated water $(>8.5 \mathrm{mg}$ $\mathrm{L}^{-1}$ ). In both cases the intermediate water layer's chemi- 


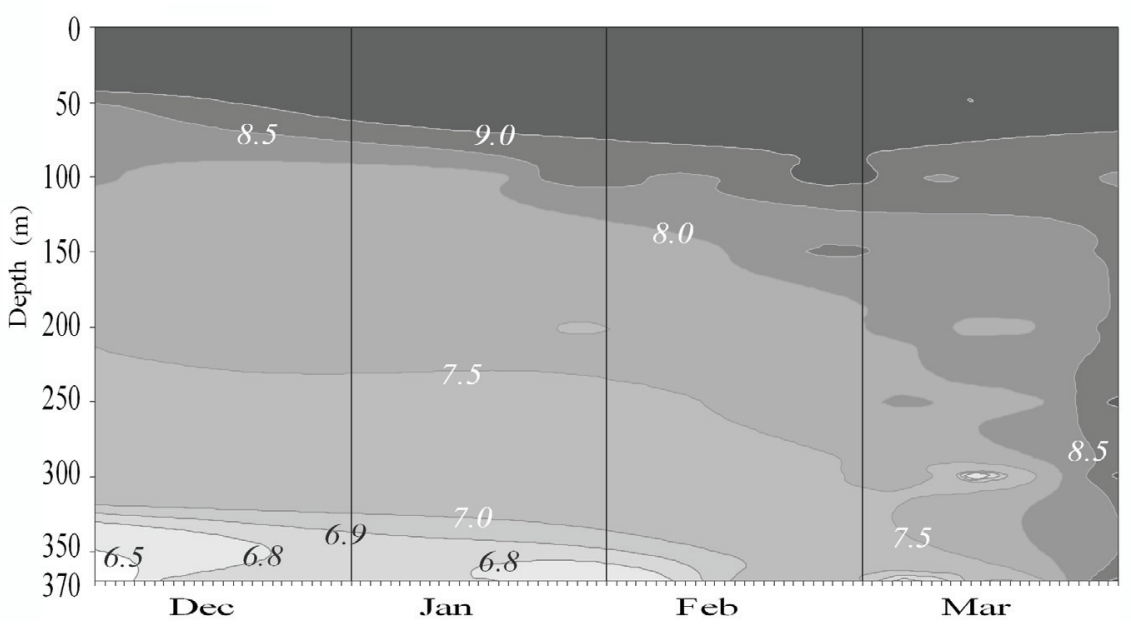

Fig. 6. Vertical distribution of dissolved $\mathrm{O}_{2}$ concentration $\left(\mathrm{mg} \mathrm{L}^{-1}\right)$ in winter 1984, showing the presence of a highly oxygenated layer below $200 \mathrm{~m}$ in mid February.

cal characteristics can be eroded progressively from both below and above, resulting at times, although not in these two examples, in complete vertical homogenization of the lake water.

The occurrence of similar events has been ascertained for Lago Maggiore in the years 1978, 1986, 1999 and 2005 (Tab. 2), and also in other great lakes of the southern Alpine district, especially in those with large catchments and therefore tributaries of considerable size, such as Lake Como. In some cases all of these water bodies have shown the same phenomenon simultaneously, confirming meteorological events of the mesoscale or larger (Ambrosetti \& Barbanti 1999).

\subsubsection{Sinking of littoral water}

From late autumn into winter in the great temperate lakes, the littoral water and the water in the shallower parts of the lake undergo faster and more intense cooling than pelagic water (Bennet 1971). Alongside the vertical temperature gradients, which during this period are lower than normal due to seasonal thermal destratification, horizontal thermal bars are formed which create additional hydrodynamic effects. Density currents with cold littoral water form where the morphology of the lake allows them. This denser water sinks and slides under the mixed layer until it meets the corresponding isopycnic line. While the water mass affected by convective motion increases in thickness, the cold water from the surface tends to penetrate at depth, contributing significantly to the exchange of mass and heat between littoral and deep zones (Naumenko 1994; Chubarenko \& Hutter 2005).

The climate of Lago Maggiore allows for the formation of such hydrodynamic processes not only during the colder winter months but also in late autumn, especially when the temperature falls rapidly. A mechanism similar in its effects but of a different origin, occurs when fallen snow close to the lake thaws. In this case, surface runoff brings cold water to the lake's edge and it subsequently sinks.

Figure 6 shows dissolved $\mathrm{O}_{2}$ concentration during an episode of sinking of littoral water in Lago Maggiore in 1984. As can be observed from the distribution of dissolved $\mathrm{O}_{2}$ at depth, the process begins in early December with $\mathrm{O}_{2}$ concentrations at their lowest, indicating possible isolation of the water mass from the remaining lake water. Subsequently, oxygen concentrations gradually increase from values below $5.5 \mathrm{mg} \mathrm{L}^{-1}$ to more than $7 \mathrm{mg} \mathrm{L}^{-1}$, and then half again by mid January. The arrival of littoral water also is confirmed by the fact that until February a clear stratification of oxygen is evident, indicating that no complete vertical mixing has occurred. While this more oxygenated layer progressively deepens, it still maintains its vertical gradient, so that there is a clear distinction between the mixing zone and hypolimnion. In addition, in the pelagic zone an evident vertical thermal gradient is present until March.

In addition to the 1984 event, this mechanism was clearly observed in Lago Maggiore in 1985 and 2009, and probably was present in 1978 and 2006 as well (see Tab. 2). Figure 7 shows the presence in mid January 2009 of a completely isolated layer below 300 meters with a concentration of dissolved $\mathrm{O}_{2}$ ranging from 6.9 $\mathrm{mg} \mathrm{L}^{-1}$ to $7.2 \mathrm{mg} \mathrm{L}^{-1}$ and later decreasing to $6.8 \mathrm{mg} \mathrm{L}^{-1}$ in February. The presence of external cold water at this depth is confirmed also by the reduction of water temperature from $6.39{ }^{\circ} \mathrm{C}$ to $6.32{ }^{\circ} \mathrm{C}$. This is related to the low atmospheric temperature of early December, and to frequent snowfall events over the entire month, but in particular to a large event on the $6^{\text {th }}$ of January. The low frequency in Lago Maggiore of this type of mechanism is due to the lake's morphometry, which consists of large areas of very deep water and smaller regions of shallow water. The mechanism is more frequent in nearby Lake Orta $\left(\mathrm{z}_{\max }=143 \mathrm{~m}\right)$ where the shallower zones are comparatively more abundant (Ambrosetti \& Barbanti 2001). 


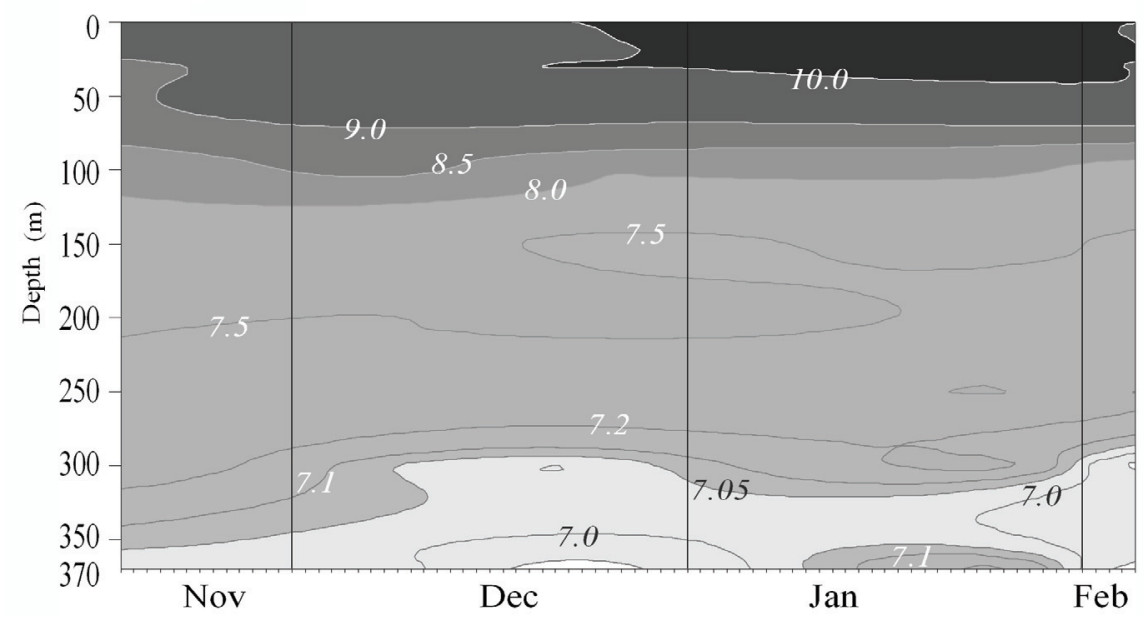

Fig. 7. Vertical distribution of dissolved $\mathrm{O}_{2}$ concentration $\left(\mathrm{mg} \mathrm{L}^{-1}\right)$ in winter 2009 , showing the presence of a highly oxygenated layer below $200 \mathrm{~m}$ in mid February.

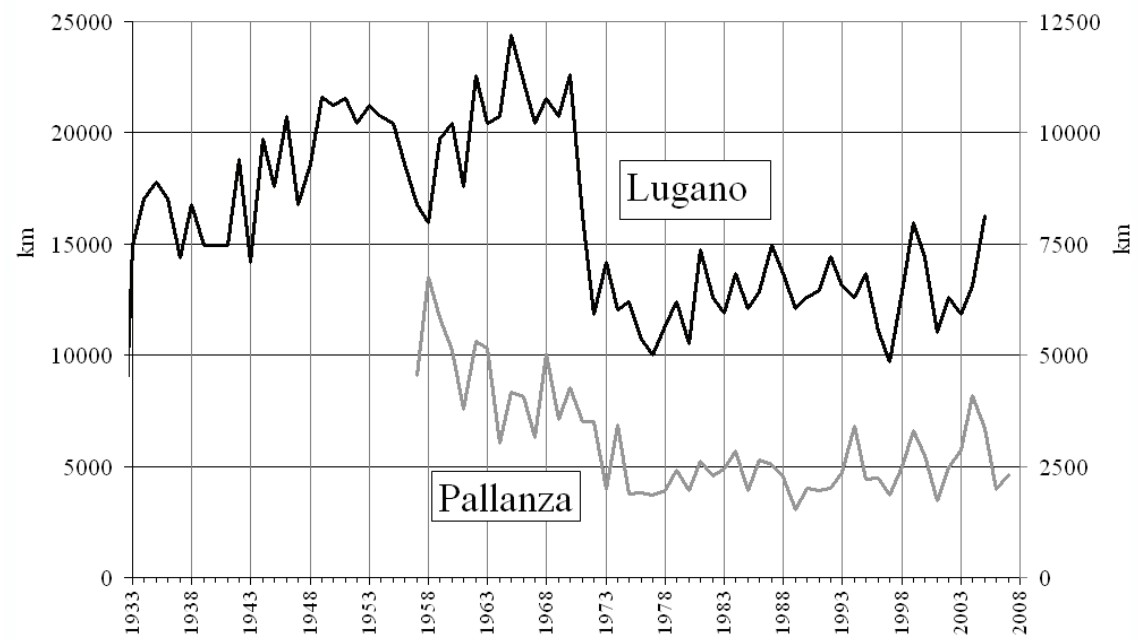

Fig. 8. Historical series of winter wind run from the Pallanza (right scale) and Lugano stations (left scale). This latter data was supplied by the Swiss Federal Office of Meteorology and Climatology.

\subsubsection{Review of mixing mechanisms}

In recent decades, atmospheric temperatures have tended to increase. From the records of the Pallanza meteorological station it appears that the warming is most noticeable with regard to maximum winter temperature. In contrast, minimum winter temperature has undergone only moderate reduction (Ambrosetti et al. 2006). The number of days with minimum temperatures above zero also has increased. These days are often characterized by temperatures higher than the seasonal average. In addition, wind run in the region of Lago Maggiore has decreased, with an especially abrupt drop after the 1960s (Fig. 8). These changes correspond to a reduction in the energy available to induce a complete winter turnover through convective motion, a phenomenon also shown by the mixing depths calculated using the parameter M (Fig. 1). However, other hydrodynamic processes outlined in the preceding sections have counterbalanced the reduction in complete mixing due to convective circulation. Table 2 lists the mixing mechanisms, the occurrence of deep water oxygenation, maximum and minimum air temperatures, number of days with frost, type of precipitation and minimum fluvial water temperature during the month in which deep water oxygenation took place.

The convective motion, which can be more or less intense, is always active during the winter cycle; however other mixing mechanisms occasionally occur either separately or in combination to augment the oxygenation of part or of the entire lake water body. In figure 1, apart from the depth reached by the mixing, the thickness of layers oxygenated by these mechanisms is indicated via the histogram. These oxygenation episodes correspond to a sudden increase in dissolved $\mathrm{O}_{2}$ content (Fig. 2). 
Tab. 2. Principal hydro-meteorological characteristics of oxygenation mechanisms in the deep lake waters from 1978 to 2006.

\begin{tabular}{|c|c|c|c|c|c|c|c|c|c|c|c|c|c|}
\hline & \multicolumn{2}{|c|}{ Periods of oxygenation } & \multicolumn{2}{|c|}{$\mathrm{T} \min \left({ }^{\circ} \mathrm{C}\right)$} & \multicolumn{2}{|c|}{ N. frost days } & \multicolumn{2}{|c|}{$\mathrm{T} \max \left({ }^{\circ} \mathrm{C}\right)$} & \multirow[t]{2}{*}{ Precipit. } & \multicolumn{2}{|c|}{$\mathrm{T}$ min rivers $\left({ }^{\circ} \mathrm{C}\right)$} & \multirow[b]{2}{*}{ period } & \multirow[t]{2}{*}{ Mechanism } \\
\hline & $1^{\prime}$ & $2{ }^{\prime}$ & Jan & Feb & Jan & Feb & Jan & Feb & & Ticino & Toce & & \\
\hline 1978 & $13 \mathrm{Apr}$ & & -3 & -2.9 & 13 & 14 & 13.1 & 11.1 & 0 & 2.2 & 4.8 & Jan & fluvial and littoral sliding \\
\hline 1981 & $5 \mathrm{Feb}$ & continue & -5.4 & -2.8 & 22 & 19 & 15.2 & 13.4 & 0 & 1.9 & 5 & Jan & conveyor belt \\
\hline 1984 & $16 \mathrm{Feb}$ & $12 \mathrm{Mar}$ & -3.4 & -3 & 15 & 10 & 7.05 & 8.5 & snow Dec & 3.8 & 4.3 & Feb & fluvial and littoral sliding \\
\hline 1985 & $31 \mathrm{Jan}-14 \mathrm{Feb}$ & 14 Mar & -8.2 & -3.5 & 21 & 23 & 10.1 & 17.3 & snow Jan & $1-2.3$ & & Jan & fluvial and littoral sliding \\
\hline 1986 & 4-11 Mar & & -3.6 & -6.9 & 10 & 14 & 14 & 12 & snow Jan-Feb & $2.8-3.2$ & 2 & Jan \& Feb & fluvial sliding \\
\hline 1991 & $26 \mathrm{Feb}$ & & -2.9 & -7 & 15 & 17 & 12 & 19 & snow Dec & 3 & 3 & Feb & fluvial sliding \\
\hline 2000 & $14 \mathrm{Feb}$ & $14 \mathrm{Mar}$ & -4.4 & -1.2 & 23 & 3 & 19 & 15.6 & 0 & $3.5-3.7$ & 3.5 & Jan & fluvial sliding \\
\hline 2004 & $15-31 \mathrm{Feb}$ & & -2.3 & -2.1 & 8 & 7 & 17.8 & 15.4 & high (Feb) & $>4.0$ & 3.8 & Feb & fluvial sliding or wind action \\
\hline 2005 & $24 \mathrm{Feb}$ & 14 Mar & -5.2 & -2.8 & 20 & 18 & 16.6 & 15.2 & 0 & $2.5-2.6$ & 4 & Jan & fluvial sliding \\
\hline 2006 & $31 \mathrm{Jan}$ & $22 \mathrm{Feb}$ & -4.5 & -2.9 & 26 & 13 & 13.4 & 11.6 & snow & 1.3 & 3 & Jan & fluvial and littoral sliding \\
\hline
\end{tabular}

On the basis of these data, it is postulated that when the deep oxygenated water occupies a relatively modest volume, such as a layer with a thickness of $<100 \mathrm{~m}$, the mechanism responsible for the event will likely be the sinking of cold littoral water. When, on the other hand, the deep oxygenation involves a layer with a larger thickness that requires greater external energy to mix, the mechanism responsible will generally be conveyor belt circulation or inflow of fluvial water. Oxygenation of deep water due to the conveyor belt mechanism, as described for the 1981 episode, typically acts alone even though in 2004 it was likely accompanied by fluvial inflow.

The historical series of mixing and relative effects can be interpreted with sufficient clarity thanks to meteorological, chemical and physical data measured in situ. Without this information, the mixing event of 2006 would likely be interpreted as a complete convective mixing when in fact it was caused by two other mechanisms. In winter the air temperature was very low, snow was abundant at low elevations, wind was almost nonexistent and at the end of January, the deep water was already more oxygenated than surface layers. This suggests the descent of littoral waters cooled by snow thawing that inserted at depths where cold fluvial waters had earlier settled (see Ticino, Tab. 2). The presence of vertical thermal gradients in the water column, in addition to the mixing depth calculated using the parameter $\mathrm{M}$ exclude the possibility of total convective mixing having created the observed temperature profile. Convective mixing was limited to only $100 \mathrm{~m}$ (Fig. 1).

Therefore, it is possible to identify the presence of an erosion process that works from the bottom of the lake and thus may be defined as 'deep erosion'. It is a dynamic process that works from the opposite direction of that of convective mixing initiated at the lake surface. Another important consideration is the fact that these oxygenation mechanisms yield more diverse ecological conditions than those due to total convective mixing, and are of a different duration.

\section{HEAT CONTENT AND WINTER STABILITY}

The quantity of heat present in lakes when winter convective mixing reaches its maximum depth also can confirm the occurrence of other hydrodynamic mecha- nisms. In Lago Maggiore this has been checked by analysing the amount of energy present in the mixed layer and in the hypolimnion. The heat content of these two layers, calculated for unit volume, is presented in figure 9 for the period 1963-2008.

The trend of heat content for the two layers, though different, shows the same tendency to increase over time. The annual variability, indicated by the respective standard deviations, is more contained in the hypolimnion $\left(0.0694 \mathrm{MJ} \mathrm{m}^{-2} \mathrm{y}^{-1}\right)$ compared to in the mixed layer $\left(0.0922 \mathrm{MJ} \mathrm{m}^{-2} \mathrm{y}^{-1}\right)$. This is a logical and expected observation given that the shallowest layer is more exposed to the stresses of the external environment.

Analysis of the trend of the heat content of the two layers also can offer information about the partial or total occurrence of vertical winter mixing (see also Figs 1 and 2). In 1963 the values for energy in the epilimnetic and hypolimnetic waters coincide due to the effect of the homogenization of the entire lake body brought about by convective mixing. However, such an event has not occurred since, and the two lines are more or less separated with regard to the heat content of the two layers. A tangible convergence of the two lines can be observed in 1999 when the shallow water, mixed by convective motion, came into contact with the inflow of fluvial water in the hypolimnion. The same situation is apparent in 1981 when conveyor belt circulation occurred. In the years affected by deep oxygenation in which there was no contact between the two layers, the distance between the lines is pronounced. The energy content difference of the epilimnion and hypolimnion is very clear.

Also from the analysis of the thermal stability trend of the lake shown in figure 9 (scale on right) it is possible to verify the mechanisms and effects of oxygenation of the deep waters at the time of maximum vertical circulation and to follow them through time. Apart from its characteristic saw-tooth trend, analogous to that verified for the heat content, these time series data have a clearly increasing trend over time that culminates in extremely high values for the last two years $(2007,2008)$. The close match between the thermal stability and the heat content of the mixed layer is expected because the major variations in thermal stability occur in the shallower portion of the lake, which is in closer contact with 


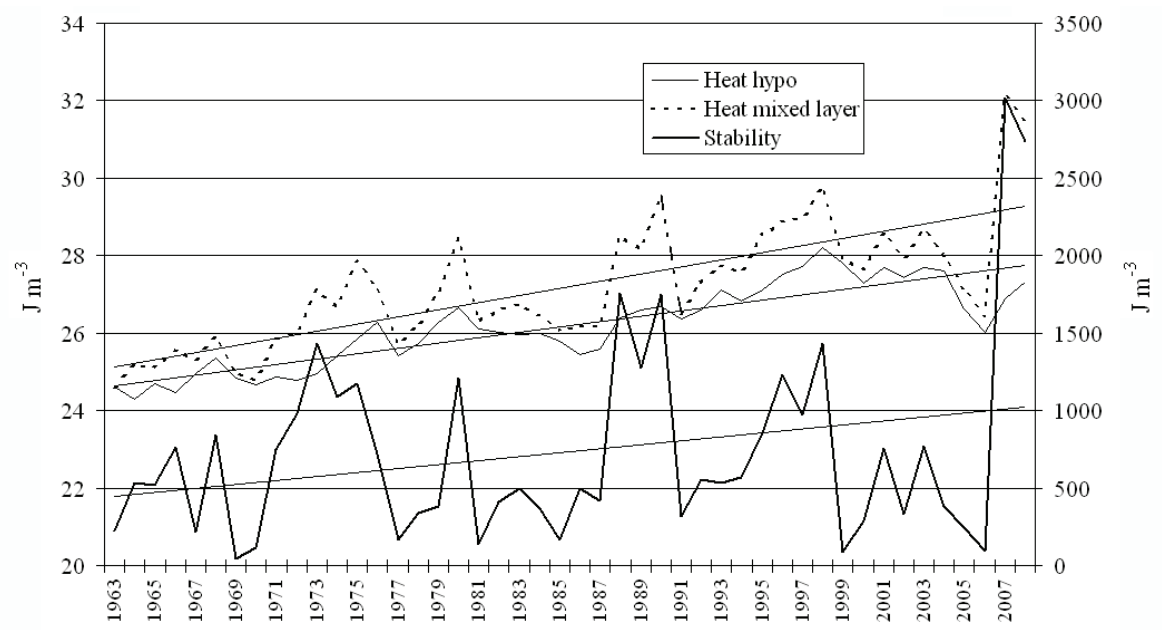

Fig. 9. Mixed layer and hypolimnion heat content for unit volume (scale on left) and total thermal stability at the time of maximum vertical circulation with relative tendency line.
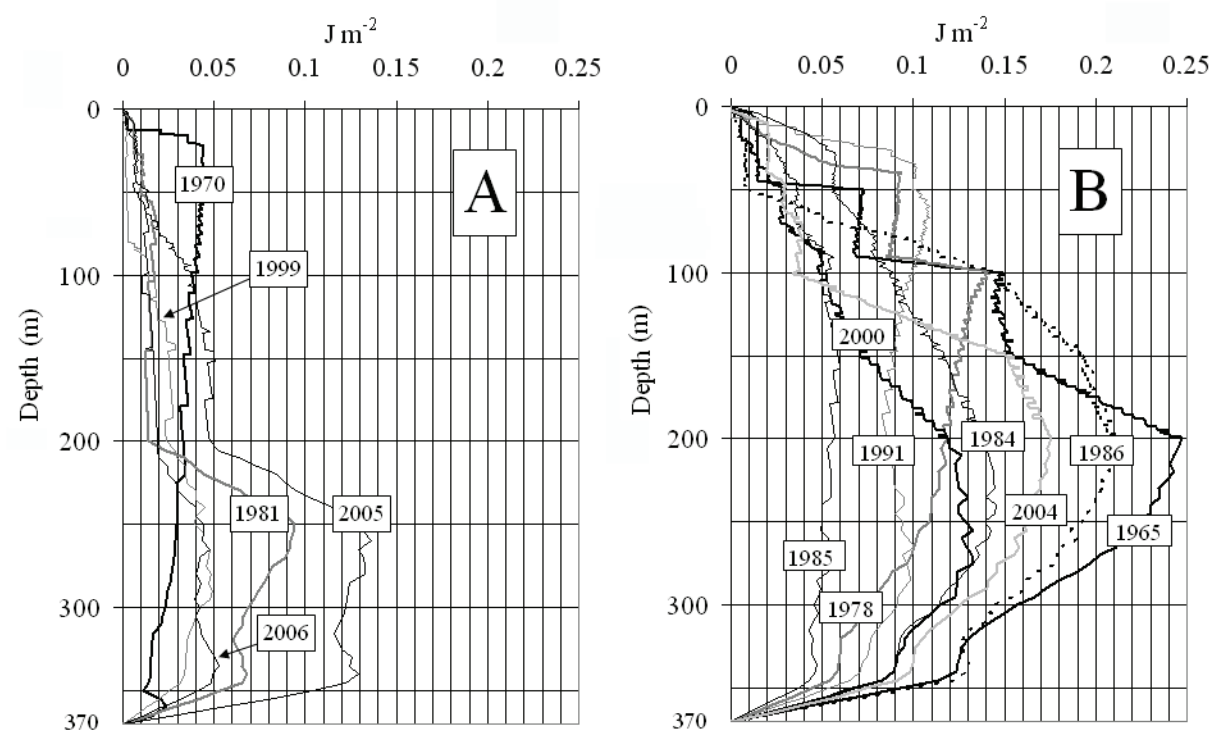

Fig. 10. Vertical thermal stability during maximum vertical circulation in the years when contact between the hypolimnion and the mixed layer occurred (A) and when no contact between the two layers occurred (B).

the external environment. The winter thermal variations, even if they are very modest, are evidently sufficient to determine differences in stability both in space (within the water column) and in time (over years). Most noticeable are the stability data from the winters of 2007 and 2008 with values greater than $3000 \mathrm{~J} \mathrm{~m}^{-2}$. These are abnormal values compared to those of the preceding years when stability did not exceed $2000 \mathrm{~J} \mathrm{~m}^{-2}$. The meteorological conditions, especially those related to temperature, were also unusual for these two seasons. In January 2007 the average atmospheric temperature was the highest of the past 50 years, as was the average temperature in February. In addition, the number of days with wind runs greater than $50 \mathrm{~km}$ per day was low. This wind intensity is the minimum needed to create the turbulence for convective mixing. Therefore, the shal- lower layers, relatively warm and of limited thickness as indicated by parameter $\mathrm{M}$, maintained their specific thermal characteristics, clearly differentiating themselves from those below. This is also demonstrated by the presence of a distinct thermal gradient $\left(0.8{ }^{\circ} \mathrm{C}\right)$ between 30 and 50 meters depth. Analogous meteorological conditions, although with less pronounced thermal characteristics, occurred in 2008 as well. In February a thermal jump of over $0.7{ }^{\circ} \mathrm{C}$ was recorded at depths between 50 and $100 \mathrm{~m}$, which led to the observed elevation of thermal stability.

In figure 10 the vertical distribution curves of thermal stability are shown. These refer to the years in which inflow of water at depth occurred. Figure 10A shows the events in which the hypolimnion came into contact with the mixed layer while figure 10B shows 

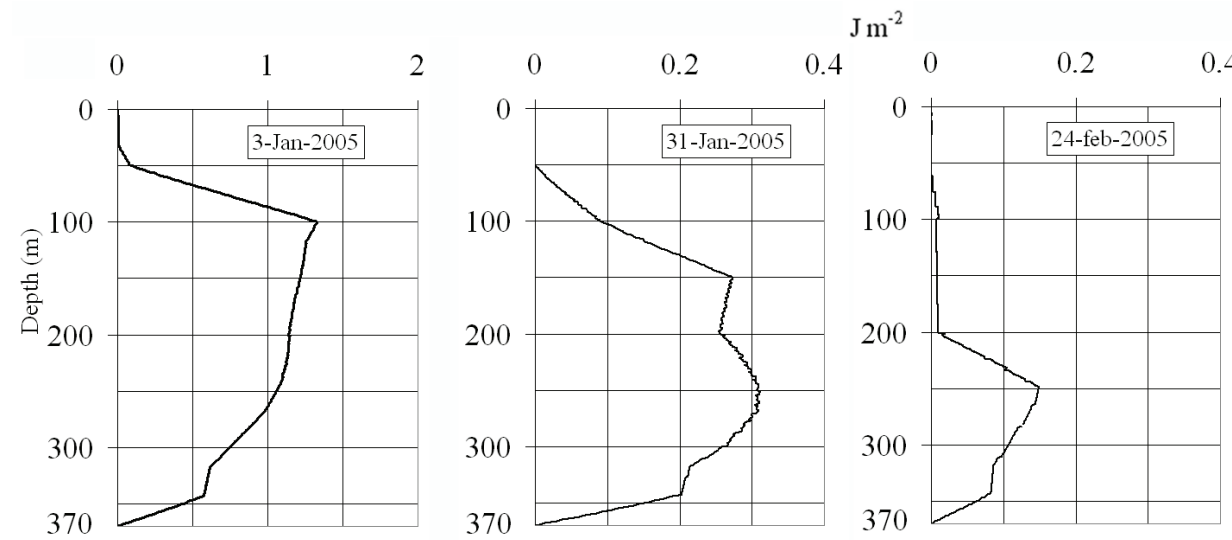

0.4

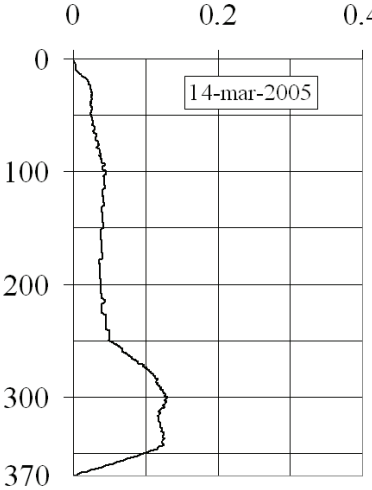

Fig. 11. Temporal sequence of the vertical distribution of the thermal stability during the 2005 winter.

those characterized by hypolimnion isolation from the mixed layer. The trend of the first group confirms that the presence of high concentrations of dissolved $\mathrm{O}_{2}$ in the deep layers is not sufficient criteria to imply a complete circulation by convective motion. Sufficiently high thermal stability values are in fact present during all these years at a depth below $200 \mathrm{~m}$, indicating a clear separation between the hypolimnion and the shallower mixed water mass. The vertical distribution of thermal stability shows very high values relative to those in the years with deep oxygenation episodes but with hypolimnion isolation (Figs 10A versus 10B).

In particular the inflow of water at depth that occurred in 2005 (Fig. 5) can be analysed through the vertical evolution of thermal stability. The 2005 thermal stability profiles shown in figure 11 indicate resistance to convective motion at the beginning of January at a depth of $50 \mathrm{~m}$ due to the persistence of thermal gradients within the water column before the bottom layers were affected by external inflows. At the end of January inflow of water at depth is indicated by the increase in thermal stability below $200 \mathrm{~m}$. Toward the end of February there is a deepening of the mixed layer and a shift of resistance to convective motion to about $200 \mathrm{~m}$, while the maximum stability values, though reduced in energy terms, remained at the same depth. Finally, the curve in March shows that convective mixing had reached at least $250 \mathrm{~m}$ depth, and a form of higher thermal stability, with a very modest value, persisted despite contact between the mixed water and the deep hypolimnion intruded by external inflow.

\section{CONCLUSIONS}

The oxygenation processes of deep water in Lago Maggiore and other large southern Alpine lakes can be driven by a variety of mechanisms depending on the dynamics of atmospheric forcing. In recent decades, autumn - winter thermal destratification has been affected by global warming, the depth reached by convective mixing gradually being reduced. However, as this paper has shown, other mechanisms determined by lake and catchment morphometry, and particular meteorological events may provide oxygen to deep waters, limiting the duration of damaging anoxia related to years of oligomixis. This is what is indicated by recent patterns of dissolved $\mathrm{O}_{2}$ in Lago Maggiore. However, where these mechanisms do not occur, either due to lake characteristics or to human impact, meromixis can develop. This has been the case in some southern Alpine lakes such as L. Lugano, L. Idro and L. Iseo (Ambrosetti \& Barbanti 2005).

Each of these mechanisms may work on its own when the external force responsible for it is dominant over the others. But more frequently they act together combining their effects, which are therefore difficult to interpret at times. The common feature of these mechanisms is that inflow of oxygenated water at depth may erode the hypolimnion without convective motion. At times, the water that arrives at the bottom remains isolated and occupies a large volume that is well defined in its chemical-physical characteristics. At other times, the erosion from the bottom reaches the overlying mixed layer. Often this event is incorrectly interpreted as total convective vertical mixing, when in reality it is due to entirely different dynamics.

The occurrence of these mechanisms can also be evaluated using the parameter $\mathrm{M}$, which calculates the depth of the mixed layer based on meteorological variables responsible for convective motion. It was shown here that these depths are in agreement with those obtained by in situ temperature and chemistry measurements. Further confirmation of the occurrence of the mechanisms is offered by the heat content and therefore by the thermal stability of the deep layer compared that of the mixed layer. These two variables clearly indicate the water body resistance to vertical mixing, which is also augmented by increasing hydrostatic pressure with depth (Imboden \& Wüest 1995).

As mentioned previously, the heat content of water in both the mixed and deeper layers shows an increase in time in Lago Maggiore. Due to the increased stability with increased heat content, it follows that in future a 
greater quantity of energy derived from external forces will be required for a complete convective mixing. This energy, however, has continued to diminish in recent decades, especially the energy derived from the wind. The quantity of heat held in the deep hypolimnion also represents the so-called 'climatic memory' as per Ambrosetti \& Barbanti (1999). Because it depends on meteorological and hydrological events that drive the lake's physical components, it offers important information on climate change.

The diverse processes that characterise lake hydrodynamics have a direct influence on a lake's water residence time, and represent the synthesis of many interactions between the lake and the surrounding environment. An exact evaluation of this parameter, in itself complex for the multiple aspects that affect it, must take into consideration internal lake hydrodynamics and in particular the lack of complete mixing that tends to prolong considerably the residence time of water in specific layers.

According to the literature, warming should have effects on aquatic ecosystems comparable to those of eutrophication (e.g., Schindler 2001). An eutrophication-like response of the zooplankton was shown in Lago Maggiore, during an exceptionally warm year (Visconti et al. 2008). Climate warming can also have indirect effects on populations and food webs by altering habitat structure in ways that change predator-prey interactions (Manca \& DeMott 2009). The mechanisms through which warming might create what is being referred to as 'internal eutrophication' are still under debate. However, residence time is widely recognized as potentially having a major role.

The effects of inflow of fluvial and littoral water at depth are not well known. This water is usually cold, oxygenated and rich in suspended particulate matter. In contrast to the convective mixing dynamic however, this inflow can trap nutrient below the photic zone, minimizing its role in promoting productivity. It has been documented that some phyto-zooplankton communities are very sensitive to lake hydrodynamics; their effects can cause community instability for an entire annual cycle (Manca et al. 2000). Therefore ecological studies in large lakes should not only consider temperature, transparency and water colour, which may be sufficient for small lakes, but should include a more comprehensive study of the physical dynamics of the water body. In addition, more detailed chemical and biological studies should be carried out to confirm the oxygenation mechanism described in this paper, including the differentiation between water of littoral, fluvial or lake surface origin, and hypolimnetic water.

\section{ACKNOWLEDGEMENTS}

We are thankful to our colleagues Oscar Ravera, Riccardo de Bernardi, Giuliano Bonomi and Marina Manca for the insightful review of this work. We would like to thank Angelo Rolla for the adaptation of the models for physical and hydrometeorological calculation. We also would like to thank Gary Bonar for editing and translating the paper and are deeply indebted to Susanne Levine for critical comment and overall revision of the English style.

\section{REFERENCES}

Ambrosetti, W. \& L. Barbanti. 1999. Deep water warming in lakes; an indicator of climatic change. J. Limnol., 58(1): 1-9.

Ambrosetti, W. \& L. Barbanti. 2001. Temperature, heat content, mixing and stability in Lake Orta: a pluriannual investigation. In: Bonacina, C. \& R. Baudo (Eds), Lake Orta: a case study. J. Limnol., 60(1): 60-68.

Ambrosetti, W. \& L. Barbanti. 2005. Evolution towards meromixis of Lake Iseo (Northern Italy) as revealed by its stability trend. J. Limnol., 64(1): 1-11.

Ambrosetti, W., L. Barbanti \& E.A.Carrara. 2007. Riscaldamento delle acque profonde nei laghi italiani: un indicatore di cambiamenti climatici. In: CNR (Ed.), Clima e Cambiamenti climatici le attività del CNR: 601-608.

Ambrosetti, W., L. Barbanti \& R. Mosello. 1982. Unusual deep mixing of Lago Maggiore during the winter 19801981. Geogr. Fis. Dinam. Quat., 5: 183-191.

Ambrosetti, W., L. Barbanti \& A. Rolla. 1983. La dinamica del mescolamento nei laghi profondi. In: Mescolamento, caratteristiche chimiche, fitoplancton e situazione trofica nei laghi profondi sudalpini. CNR, P.F. Promozione della qualità dell'ambiente, $\mathrm{AQ} / 2 / 20:$ 42-69.

Ambrosetti, W., L. Barbanti \& A. Rolla. 2006. Il clima dell'areale del Lago Maggiore durante gli ultimi cinquant'anni. (The climate of Lago Maggiore area during the last fifty years). J. Limnol., 65(Suppl. 1): 62 pp.

Ambrosetti, W., Barbanti L. \& N. Sala. 2003. Residence time and physical processes in lake. In: Papers from Bolsena Conference (2002), Science, Management, Education. J. Limnol. 62 (Suppl. 1): 1-15.

Bennet, J.R. 1971. Thermally driven lake currents during the spring and fall transition periods, Proceedings of the $14^{\text {th }}$ Conference on Great Lakes Research. Ann Arbor, Michigan, 1971: 535-544.

Calderoni, A., A. Pranzo \& G. Tartari. 1998. Indagini sull'ambiente pelagico. Chimica lacustre. In: CNR- ISE (Ed.), Ricerche sull'evoluzione del Lago Maggiore. Aspetti limnologici. Programma quiquennale1993-1997. Campagna 1997 e relazione finale. Commissione Internazionale per la protezione delle acque italo-svizzere: 41-47.

Castellano, L., W. Ambrosetti \& N. Sala. 2008. About the use of computational fluid dynamic (CFD) in the framework of physical limnological studies on a Great Lake. In: F. Orsucci \& N. Sala (Eds), Reflexing Interfaces: the Complex Coevolution of Information Technology Ecosystems. Information Science Rreference. Hershey, New York: 257-277.

Chubarenko, I. \& K. Hutter. 2005. Thermally driven interaction of the littoral and limnetic zones by autumnal cooling processes. J. Limnol., 64(1): 31-42.

Callieri, C., R. Bertoni, O. Zola \& R. Torelli. 1983. Effetti della piena circolazione sulla distribuzione verticale del materiale organico particellato nel Lago Maggiore. In: Bertoni R. \& R. de Bernardi (Eds), Atti del $5^{\circ}$ Congresso AIOL.: 217-227.

Coats, R., J. Perez-Losada, G. Schladow, R. Richards \& C. Goldman. 2006. The warming of Lake Tahoe. Climatic Change, 76: 121-148.

de Bernardi, R., G. Giussani \& I. Origgi. 1983. Analisi del popolamento zooplanctonico del Lago Maggiore nel quadriennio 1979-1982. In: C.N.R. Istituto Italiano di Idrobiologia (Ed.), Rapporti su studi e ricerche condotti nel bacino del Lago Maggiore (Campagna 1982). Commis- 
sione Internazionale per la protezione delle acque italosvizzere: $145-192$.

Ferris, J.M. 1989. LIMNO/2 A basic program for calculation of whole lake stability, heat content and volume-weighted averages of oxygen concentration and salinità. Anare research notes, 68: $22 \mathrm{pp}$.

Gorge, D.G. 1981. Wind-induced movements in the South Basin of Windermere. Freshwat. Biol, 11: 37-60.

Glen, G. 2005. The impact of year-to-year changes in the weather on the seasonal dynamics lakes. Freshwater Forum, 23: 8-19.

Haines, D.A. \& R.A. Bryson 1961. A empirical study of wind factor in Lake Mendota. Limnol. Oceanogr., 6: 336-364.

Imboden, D.M. \& A. Wüest. 1995. Mixing Mechanisms in Lakes. In: Lerman, A., D. Imboden \& J. Gat (Eds), Physics and chemistry of lakes. Spinger Verlag, Berlin: 83-135.

Lemmin, U. \& A. Amouroux. 2006 The influence of climate change on lake Geneva. Verh. Internat. Verein. Limnol., 29: 1806-1810.

Livingstone, D.M.2003. Impact of secular climate change on the thermal structure of a large temperate central European lake. Clim. Change, 57: 205-225.

Manca, M. \& W.R. DeMott. (2009). Response of the invertebrate predator Bythotrephes to a climate-linked increase in the duration of a refuge from fish predation. Limnol. Oceanogr., 54(4): (in press).

Manca, M, G. Morabito \& N. Cavicchioni. 2000. First observations on the effect of a complete, exceptional overturn of Lake Maggiore on Plankton and primary production. Int. Rev. ges. Hydrobiol., 85: 209-222.

Naumenko, M.A. 1994 Some aspects of the thermal regime of large lakes: Lake Ladoga an Lake Onega. Water Poll. Res. J. Can., 29 (2-3): 423-439.

Received: April 2009

Accepted: July 2009
Rogora, M., A. Calderoni, A. Pranzo \& G. Tartari. 2008. Indagini sull'ambiente pelagico. Chimica lacustre. Ricerche sull'evoluzione del Lago Maggiore. In: CNR-ISE (Ed.), Aspetti limnologici. Campagna 2007 e rapporto quinquennale 2003-2007. Commissione Internazionale per la protezione delle acque italo-svizzere: 45-54.

Rueda, F.V. 2006. Basin scale transport in stratified lakes and reservoirs: towards the knowledge of freshwater ecosystem. Limnetica, (1-2): 33-56.

Salmaso, N. 2005. Effects of climatic fluctuations and vertical mixing on the interannual trophic variabilità of Lake Garda, Italy. Limnol. Oceanogr., 50: 553-565.

Schindler, D.W. 2001. The cumulative effects of climate warming and other human stresses on Canadian freshwaters in the new millennium. Can. J. Fish. aquat. Sci., 58: $18-29$.

Sossau, C. \& R. Pechlaner. 1988 The regained, but hidden holomixis of Austian Lake Traunsee. Verh. Internat. Verein Limnol., 23: 74-79.

Smith, I.R. 1979. Hydraulic conditions in isothermal lakes. Freshwat. Biol., 9: 110-145.

Tikhomirov, A.I. 1982. Thermics of large lakes. Publishing house Nauka, Leningrad: $232 \mathrm{pp}$.

Vollenweider, R.A. 1964. Ueber oligomiktische Verhaltnisse des Lago Maggiore und einiger anderer insubrischer Seen. Mem. Ist. ital. Idrobiol., 17: 191-206.

Visconti, A., M. Manca, \& R. de Bernardi. 2008. Eutrophication-like response to climate warming: an analysis of Lago Maggiore (N. Italy) zooplankton in contrasting years. $J$. Limnol., 67: 87-92.

Walker, K.F. 1974. The stability of meromictic lakes in central Washington. Limnol. Oceanogr., 19: 209-222. 